\title{
Bio-Efficacy of Carbofuran 3\% CG against Whitefly, Bemisia tabaci (Gennadius) in Tomato
}

\author{
V. Anandkumar ${ }^{1^{*}}$ and K.J. Hemalatha ${ }^{2}$ \\ ${ }^{1}$ Agriculture Entomology, ICAR-Krishi Vigyan Kendra, Hagari-583 111, Ballari (Tq. \& Dist.), \\ University of Agricultural Sciences, Raichur - 584 102, Karnataka, India \\ ${ }^{2}$ Horticulture, ICAR-Krishi Vigyan Kendra, Hagari-583 111, Ballari (Tq. \& Dist.), University \\ of Agricultural Sciences, Raichur - 584 102, Karnataka, India \\ *Corresponding author
}

\section{A B S T R A C T}

An experiment was conducted to assess the bio-efficacy of Carbofuran 3\% CG against whitefly, Bemisia tabaci (Gennadius) on tomato during late kharif season of 2013-14 at Agricultural Research Station, Hagari near Ballari in Karnataka. The treatments were imposed at three different test doses along with market standard (Carbofuran 3\% G),

\section{Keywords}

Tomato, Carbofuran $3 \% \mathrm{CG}$,

Thiamethoxam $25 \%$ WG, Whitefly

Article Info

Accepted:

10 December 2017

Available Online:

10 January 2018 standard check (Thiamethoxam 25\% WG) and untreated control. Phyto-toxicity evaluation was also done for the new chemical formulation. The results showed that, 3 days after treatment imposition, Carbofuran 3\% CG at all the three doses found superior by recording lower whitefly population (2.58 to 2.80 per three leaves per plant). Market standard (Carbofuran 3\% G) and standard check (Thiamethoxam 25\% WG) recorded higher whitefly population (3.25 and 3.03 per three leaves per plant respectively) when compared to all the test doses. Similar trend were observed during seven and ten days after imposition of treatments. Correspondingly, Carbfouran 3\% CG @ $50 \mathrm{kgs} / \mathrm{ha}$ recorded higher yield of $68.3 \mathrm{q} / \mathrm{ha}$ and its lower dosages at $40 \mathrm{~kg} / \mathrm{ha}$ and $30 \mathrm{~kg} / \mathrm{ha}$ recorded $67.7 \mathrm{q} / \mathrm{ha}$ and $63.4 \mathrm{q} / \mathrm{ha}$ respectively. Observations revealed that, there was no significant difference in natural enemy population between any of the treatments. There was no record of any phyto-toxicity symptoms on tomato plants with various dosages of Carbofuran 3\% CG. From the experiment, it was confirmed that Carbofuran $3 \% \mathrm{CG}$ is effective in the management of whitefly in tomato without hindering natural enemy population and causing phyto-toxicity effect.

\section{Introduction}

Tomato, Lycopersicon esculentum (Miller) is an important vegetable crop in India and is grown on an area of 5.4 lakh hectares with a production of 7.1 million tons annually. On an average, about 10,800 tons of tomato is exported annually from India. Karnataka is a model for the country in tomato production, which is grown in an area of 46,000 hectares with 12 tons of yield per hectare.

Among the various insect pests attacking tomato that are forming limiting factors for successful cultivation of tomato, tiny whiteflies (Bemisia tabaci) poses major 
problem. These can kill off tomato plants if they aren't promptly identified and treated. They are yellow bodied insects with white wings, feed on the underside of tomato leaves by sucking out sap and weaken the plant. Affected leaves begin to yellow; leaf margins usually curl inward as damage progresses. This leads to de-vitalization of the plants, so the tomatoes do not ripen evenly and finally death of the plant. Beside these, they also secrets honey dew which creates sooty mould and there by restricting the photosynthetic activity of the plant. Apart from these, they also serve as vector for transmission of dreaded Tomato Yellow Leaf Curl Virus (TYLCV) disease.

As the pest poses multidimensional threat for the cultivation of tomato, its management is challenging to the farming community. In this context, studies were undertaken to evaluate the bio efficacy of Carbofuran 3\% CG against whitefly at various test dosages. Similar work on management of whiteflies has been conducted by (Zulfequar Ahmed and Patil, 2004), who recorded the lowest average whitefly population of 3.46 per leaf by soil application of Carbofuran $3 \mathrm{G}(15 \mathrm{~kg} / \mathrm{ha})$ in okra. The pest has developed resistance against many of the insecticides because of their indiscriminate usage. Apart from this, because of spraying, pesticide residues in the fruits are a major threat now days. In this regard, with the objective of avoiding indiscriminate use of insecticides and reducing insecticidal residues in the fruits, soil application of a new chemical formulation was evaluated against whitefly.

\section{Materials and Methods}

The present experiment work was conducted at Agricultural Research station, Hagari, Ballari in Karnataka during late kharif season on 2013-14. The experiment was laid out in Randomized Block Design (RBD) with four replications and the plot dimension was 16.2 sq.mt $(5.4 \mathrm{~m} \times 3.0 \mathrm{~m})$. One meter gap was maintained between the plot in a block and between replications. Tomato seeds were sown in $1 \mathrm{mt}^{2}$ size nursery plot under shade net. The plants were remained in the nursery till 20 days old. The seedlings were transplanted at $90 \mathrm{~cm} \times 30 \mathrm{~cm}$ spacing and the crop was maintained properly by adopting standard agronomic practices as recommended by Horticultural University, Bagalkot, Karnataka except insect pest management.

Soil application of Carbofuran 3\% CG (at various test dosages) and Carbofuran 3\% G (as market standard) were made for the control of whitefly. Apart from this, spray of Thiamethoxam 25\% WG was done against whitefly and was kept as market check. Up to more than double the highest bio-efficacy test dose was also imposed for phtyo-toxicity evaluation only. Population count of whiteflies was made on three leaves, one each from terminal, middle and lower portions of the plant. The numbers were recorded on ten plants per plot and data was presented as number per plant. The observations were made on 1 day before imposition of treatments, 3 days after imposition, 7 day after imposition and 10 days after imposition (Patil et al., 2014). At the end of last picking, total yield from each net plot was calculated and computed on hectare basis ( $\mathrm{q} / \mathrm{ha})$.

The numbers of natural enemies were recorded on ten plants per plot and data was presented as number per plant (Bharpoda et $a l ., 2014)$. The data thus obtained for whitefly, fruit yield and natural enemies were statistically analyzed following (Gomez and Gomez 1984) method to test the significance of treatment effects. In addition, phytotoxicity data was recorded for chlorosis, epinasty, hyponasty and necrosis on a scale of 0 -10, where 0 means "no phyto-toxicity" and 10 means "death of plant". 


\section{Results and Discussion}

One day before imposition of treatments, the whitefly population in all the six treatments was statistically on par with each other and ranged from 3.38 to 3.70 per three leaves per plant. At three days after imposition of treatments, Carbofuran 3\% CG at all the three doses found superior by recording lower whitefly population (2.58 to 2.80 per three leaves per plant) and were statistically on par with each other. Market standard (Carbofuran3\% G) and standard check (Thiamethoxam 25\% WG) recorded higher whitefly population (3.25 and 3.03 per three leaves per plant respectively) and statistically significant difference was found when compared to all the test doses. However, highest whitefly population (4.03 per threeleaves per plant) was noticed in untreated control and was statistically inferior to all other treatments.

Observations recorded on seven days after imposition of treatment showed similar trend with that of observations recorded at three days after imposition. The lowest whitefly population was recorded in Carbofuran 3\% CG at all the three doses (1.28 to 1.58 per three leaves per plant) which were statistically on par with each other.

These treatments were followed by standard check (Thiamethoxam 25\% WG) and market standard (Carbofuran 3\% G) which recorded higher whitefly population $(1.68 \& 2.13$ per three leaves per plant respectively) and were statistically inferior when compared to all the test doses. Untreated control continued to record higher whitefly population (4.53 per three leaves per plant).

At 10 days after imposition, the population of whitefly continued to be lowest in Carbofuran 3\% CG treatment at all three test doses $(0.60$ to 0.85 per three leaves per plant). Market standard and standard check continued to follow the similar trend with a population of 1.63 and 0.98 per three leaves per plant. Higher whitefly population was noticed in untreated control (4.65 per three leaves per plant) (Table 1). With respect to fruit yield, Carbofuran 3\% CG @ $50 \mathrm{~kg} / \mathrm{ha}$ recorded higher yield of $68.3 \mathrm{q} / \mathrm{ha}$ and its lower dosages, at $40 \mathrm{~kg} / \mathrm{ha}$ and $30 \mathrm{~kg} / \mathrm{ha}$ recorded $67.7 \mathrm{q} / \mathrm{ha}$ and $63.4 \mathrm{q} / \mathrm{ha}$ respectively. All the three test doses were statistically on par and significantly superior to rest of the treatments. Next to the test doses were Thiamethoxam $25 \%$ WG that recorded $58.4 \mathrm{q} / \mathrm{ha}$ and Carbofuran 3\% G with $55.6 \mathrm{q} / \mathrm{ha}$. Untreated control registered the lowest yield of $50.3 \mathrm{q} / \mathrm{ha}$ and was statistically inferior to all of the treatments (Table 1).

The data on the natural enemy population revealed that at all the dosages of Carbofuarn $3 \%$ CG, there were good numbers of coccinellids and spiders population. Similar trend was noticed in Carbofuran 3\% G and Thiamethoxam 25\% WG as well. Even though slightly higher natural enemy population was observed in untreated control, there was no significant difference when compared with any of the treatments (Table 2). There was no record of any phyto-toxicity symptoms on tomato plants with various dosages of Carbofuran 3\% CG (Table 3).

Among the various factors attributed to the low yield of tomato, insect pests are the major constraints and one of the key pests responsible for lower yield in tomato is whitefly. The pest not only acts as a sucking insect, but also acts as a vector for the transmission of tomato leaf curl virus diseases. Since indiscriminate spray of insecticides has led to higher resistance development in insect and increased pesticide residues in the fruits, experiment was undertaken to study the bioefficacy of new insecticidal formulation which is used against the pest by soil application. 
Table.1 Bio efficacy of carbofuran 3\% CG against whitefly in tomato during late kharif season, 2013-14

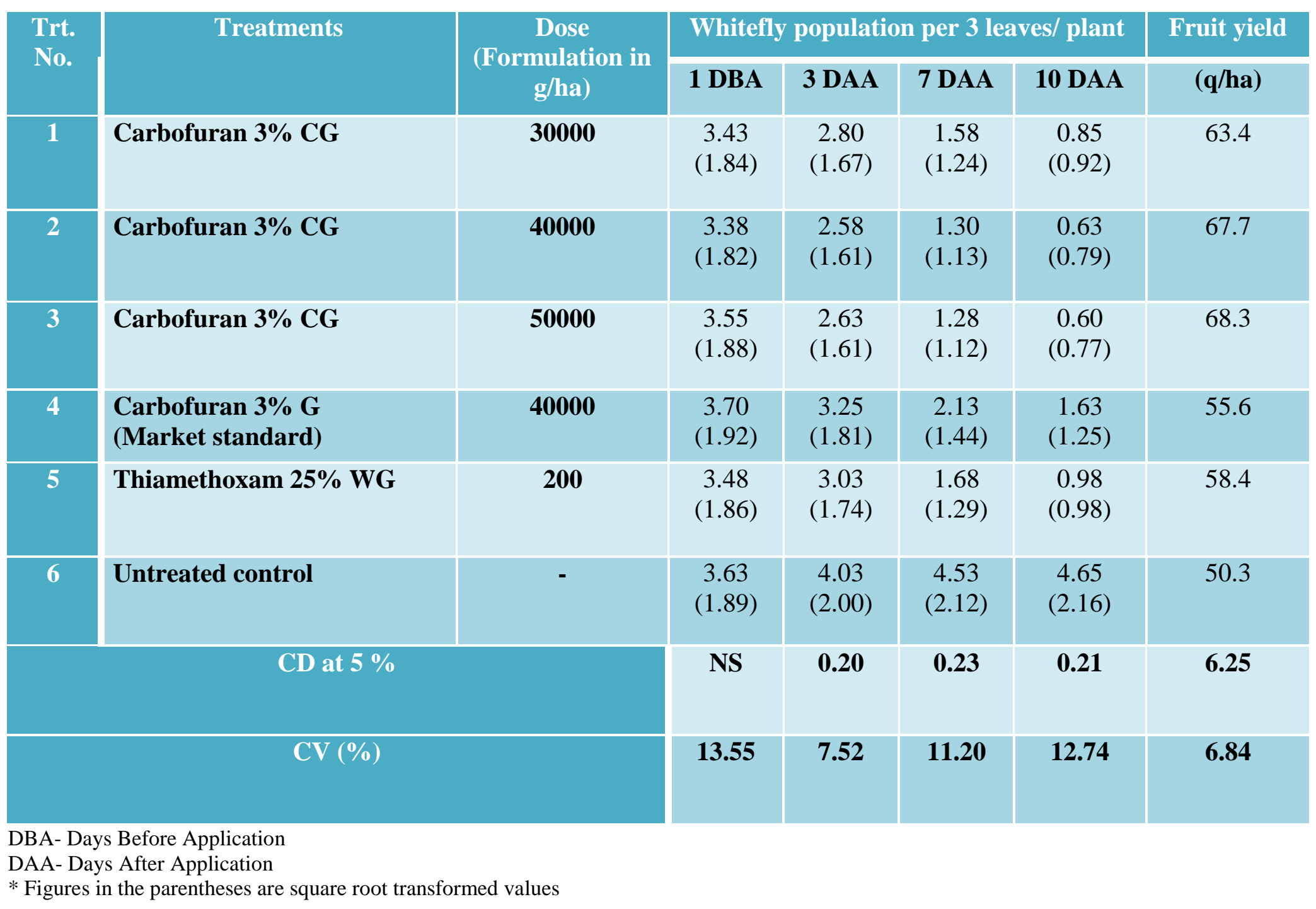


Table.2 Effect of carbofuran 3\% CG on natural enemies of tomato during late kharif season, 2013-14

\begin{tabular}{|c|c|c|c|c|c|c|}
\hline \multirow{2}{*}{$\begin{array}{l}\text { Trt. } \\
\text { No. }\end{array}$} & \multirow[t]{2}{*}{ Treatments } & \multirow{2}{*}{$\begin{array}{c}\text { Dose (Formulation in } \\
\text { g/ha) }\end{array}$} & \multicolumn{2}{|c|}{ Coccinellids } & \multicolumn{2}{|c|}{ Spiders } \\
\hline & & & 1 DBA & 10 DAA & 1 DBA & 10 DAA \\
\hline 1. & Carbofuran 3\% CG & 30000 & $\begin{array}{c}1.22 \\
(1.10)\end{array}$ & $\begin{array}{c}1.17 \\
(1.07)\end{array}$ & $\begin{array}{c}1.47 \\
(1.21)\end{array}$ & $\begin{array}{c}1.27 \\
(1.11)\end{array}$ \\
\hline 2. & Carbofuran 3\% CG & 40000 & $\begin{array}{c}1.25 \\
(1.11)\end{array}$ & $\begin{array}{c}1.20 \\
(1.09)\end{array}$ & $\begin{array}{l}1.50 \\
(1.21)\end{array}$ & $\begin{array}{l}1.32 \\
(1.14)\end{array}$ \\
\hline 3. & Carbofuran 3\% CG & 50000 & $\begin{array}{l}1.20 \\
(1.09)\end{array}$ & $\begin{array}{l}1.15 \\
(1.06)\end{array}$ & $\begin{array}{l}1.40 \\
(1.18)\end{array}$ & $\begin{array}{l}1.15 \\
(1.06)\end{array}$ \\
\hline 4. & $\begin{array}{l}\text { Carbofuran 3\% G } \\
\text { (Market standard) }\end{array}$ & 40000 & $\begin{array}{c}1.32 \\
(1.14)\end{array}$ & $\begin{array}{c}1.22 \\
(1.11)\end{array}$ & $\begin{array}{c}1.47 \\
(1.21)\end{array}$ & $\begin{array}{c}1.17 \\
(1.07)\end{array}$ \\
\hline 5. & Thiamethoxam 25\% WG & 200 & $\begin{array}{c}1.27 \\
(1.12)\end{array}$ & $\begin{array}{c}0.85 \\
(0.92)\end{array}$ & $\begin{array}{c}1.45 \\
(1.19)\end{array}$ & $\begin{array}{c}0.87 \\
(0.92)\end{array}$ \\
\hline 6. & Untreated control & - & $\begin{array}{l}1.30 \\
(1.12)\end{array}$ & $\begin{array}{l}1.35 \\
(1.16)\end{array}$ & $\begin{array}{c}1.42 \\
(1.17)\end{array}$ & $\begin{array}{c}1.55 \\
(1.23)\end{array}$ \\
\hline \multicolumn{3}{|c|}{ CD at $5 \%$} & NS & NS & NS & NS \\
\hline \multicolumn{3}{|c|}{$\mathrm{CV}(\%)$} & 15.86 & 15.33 & 16.91 & 17.03 \\
\hline
\end{tabular}

DBA- Days Before Application

DAA- Days After Application

* Figures in the parentheses are square root transformed values

Table.3 Evaluation of carbofuran 3\% CG for phyto-toxicity on tomato plants during late kharif season, 2013-14

\begin{tabular}{|c|c|c|c|c|c|c|c|c|c|}
\hline \multirow{2}{*}{$\begin{array}{l}\text { Trt. } \\
\text { No. }\end{array}$} & \multirow[t]{2}{*}{ Treatments } & \multirow{2}{*}{$\begin{array}{c}\text { Dose } \\
\text { (Formulation } \\
\text { in g/ha) }\end{array}$} & \multicolumn{7}{|c|}{ Phytotoxic grades } \\
\hline & & & Necrosis & Epinasty & Hyponasty & $\begin{array}{l}\text { Leaf tip } \\
\text { injury }\end{array}$ & $\begin{array}{l}\text { leaf injury } \\
\text { on surface }\end{array}$ & wilting & $\begin{array}{c}\text { vein } \\
\text { clearing }\end{array}$ \\
\hline 1 & Carbofuran 3\% CG & 40000 & 0 & 0 & 0 & 0 & 0 & 0 & 0 \\
\hline 2 & Carbofuran 3\% CG & 80000 & 0 & 0 & 0 & 0 & 0 & 0 & $\mathbf{0}$ \\
\hline 3 & Carbofuran $3 \%$ CG & 120000 & 0 & 0 & 0 & 0 & 0 & 0 & $\mathbf{0}$ \\
\hline 4 & Untreated control & - & $\mathbf{0}$ & 0 & 0 & 0 & 0 & 0 & 0 \\
\hline
\end{tabular}

$0=$ No phyto-toxicity and $10=$ complete mortality 
The overall mean whitefly population at 10 days after treatment imposition was lowest in the plots treated with Carbofuran 3\% CG at all the three test doses ( 0.60 to 0.85 per three leaves per plant). There are no reports available on the efficacy of Carbofuran 3\% CG against whiteflies as the chemical formulation is new. However, the efficacy of Carbofuran can be compared with the reports of (Zulfequar Ahmed and Patil, 2004) who observed the lowest whitefly population in soil application of Carbofuran $3 \mathrm{G}(15 \mathrm{~kg} / \mathrm{ha})$ plot. This also confirms the present findings of lower whitefly population in Carbofuran 3G which recorded average mean whitefly population of 1.63 per three leaves per plant. Bio efficacy of Thiamethoxam 25\% WG was superior against whiteflies on tomato (average number of 0.98 per three leaves per plant) which is in confirmation with the reports of (Naik et al., 2009) who found Thiamethoxam showing high efficacy against whiteflies. These findings are also in agreement with (Bharpoda et al., 2014) who recorded lower whitefly population (1.85/leaf) by spraying Thiamethoxam 25 WG @ $0.0125 \%$ on Bt cotton, (Patil et al., 2014) who registered lower mean whitefly population of $0.48 /$ leaf with spray of Thiamethoxam 25 WG @ $0.006 \%$ on okra and (Balaji, 2002) who reported that foliar sprays of Thiamethoxam 25 WG @ 0.025\% recorded 67.55 per cent mean reduction of whitefly population on brinjal.

The present results showed that Carbofuran 3\% CG performed well in reducing whitefly population in tomato crop, followed by Thiamethoxam 25\% WG and Carbofuran 3\% G. The use of insecticides to control whiteflies must not divert attention from the implementation of alternative pest management strategies including cultural, use of yellow sticky traps etc., which can reduce reliance to chemical products. Efforts are on to evolve suitable management strategy on whitefly which acts as a pest and vector (Puri and Mote, 2004). However, insecticides will continue to be an integral component of IPM mainly due to their effectiveness and simple use in tomato crop.

From the above conducted experiment, it can be concluded that Carbofuran 3\% CG @ $40 \mathrm{kgs} / \mathrm{ha}$ was found to be optimum dose for management of whitefly and in getting higher fruit yield in tomato. The predatory population (Coccinellids and Spiders) were statistically on par with all the dosages of Carbofuran 3\% CG and there was no phytotoxicity symptoms on tomato plants imposed with various dosages of Carbofuran 3\% CG.

\section{Acknowledgement}

The authors are thankful to Horizon Molecules Pvt. Ltd., Hyderabad for providing financial assistance and supply of Carbofuran $3 \%$ CG to carry out the research work.

\section{References}

Balaji, K. 2002. Efficacy of some new insecticides against pest complex of brinjal (Solanum melangena Linn.). M.Sc. (Ag.) Thesis, Acharya N. G. Ranga Agricultural University, Hyderabad.

Bharpoda, T. M., Patel, N. B., Thumar, R. K., Bhatt, N. A., Ghetiya, L. V., Patel, H. C. and Borad, P. K. 2014. Evaluation of insecticides against sucking insect pests infesting Bt cotton BG- II. The Bioscan, 9(3): 977-980.

Gomez, K. A. and Gomez, A. A. 1984. Statistical procedures for agricultural research, 2nd edition, Awiley inter science publication, J. Wiley and Sons, New York. pp. 302-307.

Naik, V. C. B., Rao, P. A., Krishnayya, P. V. and Chalam, M. S. V. 2009. Seasonal incidence and management of Bemisia 
tabaci (Gennadius) and Amarasca biguttulabiguttula (Ishida) of brinjal. Annals of Plant Protection Sciences, 17(1): 9-13.

Patil, S. R., Lande, G. K., Nikita S. Awasthi and Barkhade, U. P. 2014. Effect of different doses of newer insecticides against sucking pests of okra. The Bioscan, 9(4):1597-1600.

Puri, S.N. and Mote, U.N. 2004. Emerging pests problems in India and critical issues in their management: an overview. In: Frontier Areas of Entomological Research (Eds.
Subrahamaniyam, B., Ramamurthy, V.V. and Singh, V.S.) in Proceedings on the National Symposium on Frontier Areas of Entomological Research, November, 5-7, 2003, Division of Entomology, IARI, New Delhi-110012, India, pp. 13-24.

Zulfequar Ahmed and Patil M.S. 2004. Effect of Insecticides, Viricide and Plant Extract on the Incidence of Bhendi Yellow Vein Mosaic Virus and Whitefly, Bemisia tabaci Genn. Karnataka Journal of Agricultural Sciences, 17(4): 854-856.

\section{How to cite this article:}

Anandkumar, V. and Hemalatha, K.J. 2018. Bio-Efficacy of Carbofuran 3\% CG against Whitefly, Bemisia tabaci (Gennadius) in Tomato. Int.J.Curr.Microbiol.App.Sci. 7(01): 11731179. doi: https://doi.org/10.20546/ijcmas.2018.701.142 